\title{
Exploring the Science of Marma - An Ancient Healing Technique: Definition and Properties of Marma
}

\author{
Alka Mishra $^{1 *}$, Vandana Shrivastava ${ }^{1}$ \\ ${ }^{1}$ Department of Ayurveda and Holistic Health, Dev Sanskriti Vishwavidyalaya, Gayatrikunj-Shantikunj, Haridwar, India \\ *Corresponding author email: alka.mishra@dsvv.ac.in \\ https://doi.org/10.36018/dsiij.v18i.155
}

\begin{abstract}
In the vast sea of the knowledge of Ayurveda, Marma is one of the extremely important topics. Marma points have been unanimously accepted as the 'seats of life' (Prana - the vital life force). If these locations are injured, then it may lead to severe pain, disability, loss of function, loss of sensation, or death. Therefore, the ancient scriptures have strictly directed that these vital locations should not be injured, and due care should be taken in this regard even while doing surgeries. However, recent researches indicate that if there is inflammation or pain at any Marma point, then stimulating its nearby Marma points can help in alleviating this pain. This Marma Therapy has been used in treating various physical and mental disorders, with encouraging results.
\end{abstract}

In view of the importance of Marma Science mentioned in scriptures and with regards to surgeries, as well as the encouraging outcomes of Marma Therapy in recent times, the present study was undertaken for an in-depth study of the Science of Marma. Part-1 of this study gave an account of various ancient / classical Indian scriptures that mention different aspects of the Science of Marma. The present article, which is Part- 2 of this study, gives a detailed description of the number of marmas, their location, structures involved, correlation with Panchamahabhutas, classification, as well as a detailed explanation of marmaghata or viddha lakshanas (effect of trauma), as given in classical texts written during Samhita kala. The anatomical correlation with modern science is also presented.

Keywords. Ayurveda, Marma Science, Marma Therapy, Marma Classification, Marmaghata

\section{Introduction}

In the vast sea of the knowledge of Ayurveda, Marma is one of the extremely important topics. Marma point is defined as anatomical site where muscles, veins, ligaments, bones and joints meet together (Sushruta Samhita Sharira Sthana 6/16) (1). According to Acharya Sushruta there are 107 marmas in human body (Sushruta Samhita Sharira Sthana 6/3) (1). These are very important vital places, that are the 'seats of life' (Prana - the vital life force) (Ashtanga Hridaya Sharira Sthana 4/2) (2). Any injury to these parts may lead to severe pain, disability, loss of function, loss of sensation, or 
death (3). It plays an important role in surgery; therefore, it is called 'Shalya Vishayardha' (half of the entire science of surgery) (Sushruta Samhita Sharira Sthana 6/35) (1). Acharya Sushruta states that Marma sthan, a very vital point, should not be injured and should be kept intact even while doing surgeries (Sushruta Samhita Sharira Sthana 6/21) (1).

However, recent researches indicate that if any Marma point is inflamed or painful, then stimulating its nearby Marma points can help in alleviating this pain (4). Several studies and texts have reported the therapeutic benefits of Marma Therapy in treating various physical and mental disorders (3-23).

Looking at the importance of the Marma Science with regards to surgeries, as well as their recent use and future possibilities as an effective therapeutic procedure, the present study has been undertaken for an in-depth study of the Science of Marma.

An account of various ancient / classical Indian scriptures, including the Vedas, Upanishads, Puranas, Samhitas, etc. (3-10,22-35), that mention different aspects of the Science of Marma, was given in Part-1 of this study (36). The present article, which is Part- 2 of this study, gives the definition and a detailed description of the properties of Marmas, as stated in the classical texts, mostly written during Samhita kala. The description includes information about the number of marmas, their location, structures involved, correlation with Panchamahabhutas, classification, as well as a detailed explanation of marmaghata or viddha lakshanas, i.e. the effect of trauma on Marmas. The anatomical correlation with modern science is also presented.

\section{Derivation of the Word 'Marma'}

The origin of word 'Marma' can be traced in various texts as follows:

\section{Amarakosha}

$$
\text { मृ - मनिन् , मृ + प्राणत्यागे }
$$

(Amarakosha 3/5/30) (37)

Amarakosha (37) explains that the word marma is derived from the sanskrit term 'mri- manin' or 'mripranatyage'. It means that which causes death or death like miseries.

\section{Shabdakalpadruma}

$$
\text { मृ + 'सर्व्वधातुभ्यो मनिन्' }
$$

(Shabdakalpadruma 4/144, chapter 3, pg. 941) (38)

Shabdakalpadruma (38) mentions that the word marma is derived from 'mri' dhatu. Its meaning is explained as sandhisthanam (i.e. joining point of various structures) or jeevasthanam (seats of life) (38).

\section{Raj Nighantu}

मृ - मनिन्, जीव स्थाने: संधि स्थाने तात्पर्ये च।

(Raj Nighantu, Manushya Varga / 64) (39)

Raj Nighantukara opines that the word marma is derived from 'mri - manin', which means seat of life (jeevasthana) or conglomeration of many important structures (sandhi sthana) (39).

Thus, based on the above descriptions, Marma is derived from the root word 'mri' with suffix 'manin'. The word 'Marman' is the singular form, which means jeevasthanam (seat of life) or sandhisthanam (meeting place).

Etymologically each letter of word marma has got specific meaning - 'Ma' means prana or vayu, Repha denotes house or seat. Therefore, 'Marma' means seat of Prana or Vayu, where Prana is the vital life 
force that governs all the physical and subtle processes of a living being (40-43).

\section{Definitions of 'Marma'}

According to Acharya Sushruta

मर्माणि मांससिरास्नाट्वस्थिसन्धिसन्निपाता:, तेषु स्वभावत एव विशेषेण प्राणास्तिष्ठन्ति।

(Sushruta Sharira 6/15) (1)

Marma (fatal spots) are confluence of muscles, veins, ligaments, bones and joints. These are the places where the Prana (vital life force) resides naturally (1).

\section{According to Ashtanga Sangraha}

तत्पुन: मांससिरास्नाय्वस्थिसन्धिसन्निपातः।

तेन तस्मिन् पीड्यमाने विशेषत: प्राणबाधः॥

(Ashtanga Sangraha Sharira 7/28) $(44,45)$

Marmas are the sites where muscles, veins, ligaments, bones and joints meet. If they get traumatized, Prana gets destroyed $(44,45)$.

\section{According to Ashtanga Hridaya}

\section{मांसास्थिस्नायुधमनीसिरासन्धिसमागमः ।}

(Ashtanga Hridaya Sharira 4/38) (2)

Marmas are the sites where muscles, bones, ligaments, artery, veins and joints meet each other (2). Prana is especially located there, and if they get afflicted, it may lead to death.

\section{According to Acharya Chakrapani}

$$
\text { तच्च मांस सिरास्नायवस्थिसंधिषु निविष्टम्। }
$$

(Charaka Siddhi 9/3, Chakrapani Tika) (46)

The meeting point of muscle, vein, ligament, bone and joint is called Marma, which are dependent on these components (46).
According to Acharya Aruna Dutta मरणकारित्वान्मर्म, मरणसदृशदु:खादयित्वाद्वा।

(Ashtanga Hridaya Sharira, Aruna Dutta Tika 4/37) (47)

Those locations, which when injured lead to destruction of life, are called Marmas $(24,47)$.

\section{According to Acharya Bhava Prakash}

सन्निपात: सिरास्नायु संधिमांसास्थि सम्भव:।

मर्माणि तेषु तिष्ठन्ति प्राणा: खलु विशेषतः ॥

(Bhava Prakash, Purva Khand, Garbha Prakaran 3/223) $(48,49)$

The meeting point of vein, ligament, joint, muscle and bone is called Marma point $(48,49)$. Prana especially resides in these points $(48,49)$.

\section{Lakshanas (Nature / Signs) of Marma}

According to Acharya Sushruta मर्माणि मांससिरास्नाय्वस्थिसन्धिसन्निपाता:,

$$
\begin{aligned}
& \text { तेषु स्वभावत एव विशेषेण प्राणास्तिष्ठन्ति, } \\
& \text { तस्मान्मर्मस्वभिहतास्तांस्तान् भावानापद्यन्ते ॥ } \\
& \text { (Sushruta Sharira 6/15) (1) }
\end{aligned}
$$

Marma (fatal spots) are confluence of muscles, veins, ligaments, bones and joints (1). Prana (vital life force) especially resides in these locations; hence if the Marmas are injured, they produce their respective effect (1).

\section{According to Acharya Dalhana$$
\text { मारयन्तीति मर्माणि।। }
$$

(Sushruta Sharira, Dalhan Tika 6/3) (50)

Any injury to marma points may lead to death $(21,24,28)$.

\section{According to Acharya Vagabhatta

$$
\text { विषमं स्पन्दनं यत्र पीडिते रुक् च मर्म तत् ॥ }
$$

(Ashtanga Hridaya Sharira 4/37) (2)

That part of the body is Marma, where, on giving extreme (extraordinary) spandan (vibration) or on pressing, there is extraordinary pain (2). 


\section{According to Acharya Charaka}

तेषामन्यतमपीडायां समधिका पीडा भवति, चेतनानिबन्धवैशेष्यात ।

(Charaka Samhita Siddhi 9/3) (51)

In case of affliction in any marma point, there is more pain (excruciating type) than any other part of the body, because of the specific attachment of chetana (consciousness) to these spots (51).

\section{According to Acharya Sharangadhara}

मर्माणि जीवधाराणि प्रायेण मुनयो जगु:॥

(Sharangadhara Samhita, Purva Khand, 5/39) (52)

The Marma points in the body are mostly the foundational locations of life - this has been told by the ancient sages (52). Prana especially resides in the Marma locations.

\section{According to Acharya Bhava Prakash}

मर्माणि तेषुतिष्ठन्ति प्राणा: खलु विशेषतः।

(Bhava Prakash, Purva Khanda 3/223) $(48,49)$

Marma spots are specific location of prana (vital life force) $(48,49)$.

\section{According to Raj Nighantu}

$$
\text { जीव स्थाने: संधि स्थाने तात्पर्ये च। }
$$

(Raj Nighantu, Manushya Varga / 64) (39)

Marmas are seats of life (jeevasthana) and meeting point of many important structures (sandhisthana) (39).

All the above lakshanas show the importance and vitality of Marma points. Any injury, trauma or disease affecting Marma will cause death or miseries equal to death.

\section{Classification of Marmas}

In the ancient scriptures, Marmas have been classified in different ways, such as their location in different regions of the body, anatomy, size, effect of trauma on these, etc. This section illustrates the different types of classifications of Marmas.

Classification of Marmas according to their Location in different Regions of the Body

Table 1 gives the classification of Marmas according to their location in different regions of the body, i.e. upper limbs (22), lower limbs (22), abdomen and chest (12), back (14), supraclavicular region (neck and head) (37).

Anatomical classification of Marmas according to Acharya Sushruta

Acharya Sushruta (1) has classified Marmas into five types according to the Dhatu from which they are made. These types include Mamsa (Muscle), Asthi (Bone), Snayu (Ligament), Sira (Vessel) and Sandhi (Joint) (1).

\section{Anatomical Classification of Marmas according to}

\section{Acharya Vagbhatta}

Acharya Vagbhatta has classified Marmas into six types according to the Dhatu bheda (2). He has added one additional Marma named 'Dhamani Marma' (2). These types include Mamsa (Muscle), Asthi (Bone), Snayu (Ligament), Dhamani (Artery), Sira (Vein) and Sandhi (Joint) (2).

Names of Marmas included under different anatomical classes

Table 2 gives the Names of Marmas included under different anatomical classes, i.e. Mamsa Marma (11), Sira Marma (41), Snayu Marma (27), Asthi Marma (8), Sandhi Marma (20), and Dhamani Marma (9). 


\begin{tabular}{|c|c|c|c|c|c|c|}
\hline \multirow[t]{2}{*}{$\begin{array}{l}\text { Urdhva Shakhagata } \\
\text { (Upper limbs) } \\
\text { (11X2) }\end{array}$} & \multirow[t]{2}{*}{$\begin{array}{l}\text { Adho Shakhagata } \\
\text { (Lower limbs) } \\
(11 \times 2)\end{array}$} & \multicolumn{2}{|c|}{$\begin{array}{c}\text { Udaragata (Abdomen) \& } \\
\text { Urogata (Thorax) } \\
(12)\end{array}$} & \multirow[t]{2}{*}{$\begin{array}{l}\text { Prishthagata } \\
\text { (Back) } \\
\text { (7X2) }\end{array}$} & \multicolumn{2}{|c|}{$\begin{array}{c}\text { Urdhwajatrugata } \\
\text { Supraclavicular region) } \\
(37)\end{array}$} \\
\hline & & $\begin{array}{c}\text { Abdomen } \\
\text { (3) }\end{array}$ & $\begin{array}{c}\text { Thorax } \\
\text { (9) }\end{array}$ & & $\begin{array}{c}\text { Neck } \\
\text { (14) }\end{array}$ & $\begin{array}{l}\text { Head } \\
(23)\end{array}$ \\
\hline Talahridaya-2 & Talahridaya-2 & Guda-1 & Hridaya-1 & Amsa-2 & Nila-2 & Vidhura-2 \\
\hline Kshipra-2 & Kshipra-2 & Vasti-1 & Stanamula-2 & Amsaphalaka-2 & Manya-2 & Phana-2 \\
\hline Kurcha-2 & Kurcha-2 & Nabhi-1 & Stanarohita2 & Vrihati-2 & Matrika-8 & Apanga-2 \\
\hline Kurchashira-2 & Kurchashira-2 & & Apalapa-2 & Parshvasandhi-2 & Krikatika-2 & Avarta-2 \\
\hline Manibandha-2 & Gulpha-2 & & Apastambha-2 & Nitamba-2 & & Utkshepa-2 \\
\hline Indravasti-2 & Indravasti-2 & & & Kukundara-2 & & Shankha-2 \\
\hline Kurpara-2 & Janu-2 & & & Katikataruna-2 & & Sthapani-1 \\
\hline Ani-2 & Ani-2 & & & & & Shringataka-4 \\
\hline Urvi-2 & Urvi-2 & & & & & Simanta-5 \\
\hline Lohitaksha-2 & Lohitaksha-2 & & & & & Adhipati-1 \\
\hline Kakshadhara-2 & Vitapa-2 & & & & & \\
\hline
\end{tabular}

Table 1. Marmas in different regions of the body. (The numeric digits next to the Marmas state their respective numbers in the body)

\begin{tabular}{|c|c|c|c|c|c|c|}
\hline \multirow{2}{*}{$\begin{array}{c}\text { *Mamsa Marma } \\
\text { (11) }\end{array}$} & \multicolumn{2}{|c|}{$\begin{array}{c}\text { *Sira Marma } \\
\text { (41) }\end{array}$} & \multirow{2}{*}{$\begin{array}{c}\text { *Snayu Marma } \\
(27)\end{array}$} & \multirow{2}{*}{$\begin{array}{c}\text { *Asthi Marma } \\
\text { (8) }\end{array}$} & \multirow{2}{*}{$\begin{array}{c}\text { *Sandhi Marma } \\
(\mathbf{2 0}) \\
\text { Janu (2) }\end{array}$} & \multirow{2}{*}{$\begin{array}{c}\text { \#Dhamani Marma } \\
(9)\end{array}$} \\
\hline & Urvi (4) & Nabhi (1) & & & & \\
\hline Indravasti (4) & Lohitaksha (4) & Nila (2) & Kurchashira (4) & Nitamba (2) & Kurpara (2) & Apastambha(2) \\
\hline Stanarohita(2) & Vrihati (2) & Manya (2) & Kshipra (4) & Ansaphalaka(2) & Gulpha (2) & Vidhura (2) \\
\hline \multirow[t]{7}{*}{ Guda (1) } & Parshvasandhi(2) & Matrika (8) & Ani (4) & Shankha (2) & Manibandha(2) & Shringataka (4) \\
\hline & Hridaya (1) & Shringataka(4) & Kakshadhara(2) & & Kukundara (2) & \\
\hline & Stanamula (2) & Apanga (2) & Vitapa (2) & & Krikatika (2) & \\
\hline & Apalapa (2) & Phana (2) & Ansa (2) & & Simanta (5) & \\
\hline & Apasthambha(2) & Sthapni (1) & Basti (1) & & Adhipati (1) & \\
\hline & & & Utkshepa (2) & & Avarta (2) & \\
\hline & & & Vidhura (2) & & & \\
\hline
\end{tabular}

Table 2. Names of Marmas included under different anatomical classes. (The numeric digits next to the Marmas state their respective numbers in the body). * According to Acharya Sushruta (Sushruta Samhita, Sharira Sthana, Chapter 6) (1). "According to Acharya Vagbhatta (Ashtanga Hridaya, Sharira Sthana, Chapter 4) (2).

\section{Classification according to the Size of Marmas}

The Size of Marma varies from ardha-anguli (half finger) to hatheli (palm) or mushti (fist). Out of 107 marmas, 56 are of half finger size, 12 are of one finger size, 6 are of two finger size, 4 are of three finger size, and 29 are of one palm or one fist size (Sushruta Sharira 6/28-30) (1). 


\begin{tabular}{|c|c|c|c|c|c|}
\hline $\begin{array}{c}\text { Eka anguli pramana } \\
\text { (1 finger size) } \\
\text { (12) }\end{array}$ & $\begin{array}{l}\text { Dwi anguli pramana } \\
\text { (2 finger size) } \\
\text { (6) }\end{array}$ & $\begin{array}{l}\text { Tri anguli pramana } \\
\text { (3 finger size) } \\
\text { (4) }\end{array}$ & $\begin{array}{l}\text { Eka hatheli/ mushti } \\
\text { pramana (1 palm / fist size) } \\
\text { (29) }\end{array}$ & \multicolumn{2}{|c|}{$\begin{array}{l}\text { Ardha-anguli pramana } \\
\text { (Half finger size) } \\
(56)\end{array}$} \\
\hline Urvi (4) & Gulpha (2) & Janu (2) & Kurcha (4) & Kshipra (4) & Vrihati (2) \\
\hline Kurchashira (4) & Manibandha (2) & Kurpara (2) & Guda (1) & Talahridaya (4) & Ansa (2) \\
\hline Vitapa (2) & Stanamula (2) & & Vasti (1) & Indrabasti (4) & Ansaphalaka(2) \\
\hline \multirow[t]{9}{*}{ Kakshadhara (2) } & & & Nabhi (1) & Ani (4) & Krikatika (2) \\
\hline & & & Hridaya (1) & Lohitaksha (4) & Vidhura (2) \\
\hline & & & Nila (2) & Apalapa (2) & Phana (2) \\
\hline & & & Manya (2) & Apasthambha(2) & Apanga (2) \\
\hline & & & Matrika (8) & Stanarohita (2) & Avarta (2) \\
\hline & & & Simanta (5) & Katikataruna (2) & Utkshepa (2) \\
\hline & & & Shringataka (4) & Kukundara (2) & Shankha (2) \\
\hline & & & & Nitamba (2) & Sthapani (1) \\
\hline & & & & Parshvasandhi(2) & Adhipati (1) \\
\hline
\end{tabular}

Table 3. Classification according to the Size of Marmas (Sushruta Sharira, 6/28-30) (1). (The numeric digits next to the Marmas state their respective numbers in the body)

\section{Classification according to the Result / Outcome (Symptoms if Injured)}

Table 4 gives the prognostic classification of Marmas, i.e. the classification according to the symptoms observed upon injury to a Marma point, which include Sadyah Pranahara (Immediate death causing) (19), Kalantara Pranahara (Death causing after some time) (33), Vishalyagha (Fatal after removal of foreign material) (3), Vaikalyakara (Disabling) (44), and Rujakara (Painful)

\begin{tabular}{|c|c|c|c|c|c|c|}
\hline $\begin{array}{l}\text { Sadyah Pranahara } \\
\text { (Immediate death } \\
\text { causing) (19) }\end{array}$ & $\begin{array}{r}\text { Kalantara } \\
\text { (Death causing }\end{array}$ & $\begin{array}{l}\text { Pranahara } \\
\text { after some time) } \\
\text { 3) }\end{array}$ & $\begin{array}{c}\text { Vishalyagha } \\
\text { (Fatal after removal } \\
\text { of foreign material) } \\
\text { (3) }\end{array}$ & \multicolumn{2}{|c|}{$\begin{array}{c}\text { Vaikalyakara (Disabling) } \\
\text { (44) }\end{array}$} & \multirow{2}{*}{$\begin{array}{c}\begin{array}{c}\text { Rujakara } \\
\text { (Painful) (8) }\end{array} \\
\text { Gulpha (2) }\end{array}$} \\
\hline Guda (1) & Kshipra (4) & Stanamula (2) & Utkshepa (2) & Lohitaksha (4) & Ansa (2) & \\
\hline Vasti (1) & Talahridaya (4) & Simanta (5) & Sthapani (1) & Ani (4) & Ansaphalaka(2) & Manibandha(2) \\
\hline Nabhi (1) & Indrabasti (4) & Katikataruna (2) & & Urvi (4) & Krikatika (2) & Kurchashira(4) \\
\hline Hridaya (1) & Apalapa (2) & Parshvasandhi(2) & & Kurcha (4) & Nila (2) & \\
\hline Matrika (8) & Apasthambha(2) & Vrihati (2) & & Janu (2) & Manya (2) & \\
\hline Shankha (2) & Stanarohita (2) & Nitamba (2) & & Kurpara (2) & Vidhura (2) & \\
\hline Shringat(4) & & & & Vitapa (2) & Phana (2) & \\
\hline \multirow[t]{2}{*}{ Adhipati (1) } & & & & Kakshadhara(2) & Apanga (2) & \\
\hline & & & & Kukundara (2) & Avarta (2) & \\
\hline
\end{tabular}

Table 4. Prognostic classification of Marmas (Sushruta Sharira, 6) (1). (The numeric digits next to the Marmas state their respective numbers in the body) 
Classification of Marmas according to Panchabhautika guna (Sushruta Sharira, Chapter 6) (1)

The classification of Marmas according to Panchabhautika guna is similar to the prognostic classification given in Table 4, wherein the correspondence between the Panchabhautika guna and the prognostic classification is as follows -

1) Agneya (having fire quality) (19) - these are Sadyah Pranahara Marma

2) Saumyagneya (having fire \& water qualities) (33) - these are Kalantara Pranahara Marma

3) Vayavya (having air quality) (3) - these are Vishalyaghna Marma

4) Saumaya (having water quality) (44) - these are Vaikalyakara Marma

5) Vayavya (having air with little fire quality) (8) these are Rujakara Marma

Nature of Fatal Spots (Qualities of Marma or correlation with Pancha Mahabhutas)

The nature of Sadyah Pranahara marma is Agneya, i.e. having qualities of fire; therefore, owing to this fire like (sharp) quality, injury to these marma kills the affected person quickly (Sushruta Sharira 6/16) (1). The fatal time period of Sadyah Pranahara marma is less than seven days (Sushruta Sharira 6/23) (1). These marma are nineteen in number (Sushruta Sharira 6/8) (1). If an injury occurs at the border or nearby area of the location of Sadyah Pranahara marma, the occurrence of death is slightly delayed, i.e. the effect is similar to that of Kalantar Pranahara marma (Sushruta Sharira 6/22) (1).

The nature of Kalantar Pranahara marma is Saumyagneya, i.e. having qualities of both fire and water; therefore, although due to their fire like nature, an injury to these marma kills the affected person quickly, but because of the cold and stable nature of soma (water), the occurrence of death is delayed (Sushruta Sharira 6/16) (1). For Kalantar Pranahara marma, the fatal time period is from fifteen days to one month (Sushruta Sharira 6/23) (1). These are thirty three in number (Sushruta Sharira 6/8) (1). If an injury occurs at the border or nearby area of the location of Kalantar Pranahara marma, it causes deformity, i.e. the effect is similar to that of Vaikalyakara marma (Sushruta Sharira 6/22) (1).

Vishalyaghna marma are Vayavya, i.e. having qualities of air. If these marma are injured by a shalya (foreign body), then because of their Vayavya nature, as long as the air remains obstructed inside (i.e. prevented from coming out) by the mass of the shalya (foreign body), the person stays alive, but as soon as the foreign body is pulled out, the air residing in the fatal spot comes out and the person dies. However, after the injury, if the shalya is not pulled out before the completion of the auto healing process, then it provides protection to the Prana at that location untill the wound is healed normally, and the shalya is pulled out along with pus (Sushruta Sharira 6/16) (1). Vishalyaghna marma may also sometimes lead to death if these are heavily injured (Sushruta Sharira 6/23) (1). These are three in number (Sushruta Sharira 6/8) (1). If an injury occurs at the border or nearby area of the location of Vishalyaghna marma, it causes deformity, i.e. the effect is similar to that of Vaikalyakara marma (Sushruta Sharira 6/22) (1).

Vaikalyakara marma are Saumya, i.e. having qualities of moon / water. Because of the stability and cold property of Soma guna, these help in the sustenance of life (Sushruta Sharira 6/16) (1). Vaikalyakara marma may also sometimes lead to 
death if these are heavily injured (Sushruta Sharira 6/23) (1). These are forty four in number (Sushruta Sharira 6/8) (1). If an injury occurs at the border or nearby area of the location of Vaikalyakara marma, it harms the body after some time and also produces pain, i.e. the effect is similar to that of Rujakara marma (Sushruta Sharira 6/22) (1).

Rujakara marma predominantly have the properties of fire and air, both of which produce pain (Sushruta Sharira 6/16) (1). Although Agni is diminished because of trauma, yet Vayu causes constant pain at the affected part. These are eight in number (Sushruta Sharira 6/8) (1). If an injury occurs at the border or nearby area of the location of Rujakara marma, it causes severe pain (Sushruta Sharira 6/22) (1).

\section{Location, Anatomical Correlation, Size and Number of Marmas}

With reference to the above mentioned details about Marmas, in modern times, several studies have acknowledged the importance of Marmas (53-60), and several others have been conducted with regards to studying / ascertaining the location, anatomy, size, and other properties of the Marmas $(17,19,20,27-$ 33,35,61-68).

Table 5 to Table 10 give the location, anatomical correlation with modern science, size and number of Marmas of different parts of the body, i.e. Upper Extremities, Lower Extremities, Abdomen, Thorax, Back, and Supraclavicular region, respectively $(3,7,10)$. Figure 1 gives the location and size of individual Marmas in the Shadanga Sharira (entire body) (35).

\begin{tabular}{|c|c|c|c|c|c|}
\hline \multicolumn{6}{|c|}{ Marmas of Upper Extremities (22 in number) } \\
\hline S. & Marma & Location $(1,3,10)$ & Anatomical Correlation (3) & Size (1) & No. \\
\hline 1 & Talahridaya & $\begin{array}{l}\text { In the palm's center, in line of middle finger, just below } 3^{\text {rd }} \\
\text { metacarpo-phalangeal joint }\end{array}$ & Palmer Aponeurosis & 1/2finger & 2 \\
\hline 2 & Kshipra & Between index finger and thumb & $1^{\text {st }}$ Inter Metacarpal Ligament & 1/2finger & 2 \\
\hline 3 & Kurcha & From thumb's base, 1 finger above (proximal) & \multicolumn{2}{|c|}{ Carpometacarpal \& Intercarpal Ligament 1 palm } & 2 \\
\hline 4 & Kurchashira & 1 finger below Kurcha, below wrist joint & Lateral Ligament of Wrist Joint & 1 finger & 2 \\
\hline 5 & Manibandha & On top of the wrist & Wrist Joint & 2 finger & 2 \\
\hline 6 & Indravasti & In the mid-line of hand, 4 finger below elbow crease & Origin of Palmer Longus Muscle & 1/2finger & 2 \\
\hline 7 & Kurpara & On the either side of the elbow joint & Elbow Joint & 3 finger & 2 \\
\hline 8 & Ani & $\begin{array}{l}\text { Just medial to mid-line of the hand, } 3 \text { fingers above elbow } \\
\text { joint }\end{array}$ & Tendon of Bicep Muscle & 1/2finger & 2 \\
\hline 9 & Urvi & 4 fingers above Ani, in mid of arm & Brachial Artery & 1 finger & 2 \\
\hline 10 & Lohitaksha & Medial to mid-line of hand, over anterior axillary fold & Brachial Plexus & 1/2finger & 2 \\
\hline 11 & Kakshadhara & $\begin{array}{l}\text { Below lateral } 1 / 3^{\text {rd }} \text { of clavicle and medial to head of } \\
\text { humerus, in delto-pectoral groove }\end{array}$ & Axillary Vessels & 1 finger & 2 \\
\hline
\end{tabular}

Table 5. Location, anatomical correlation, size and number of Marmas of Upper Extremities. 


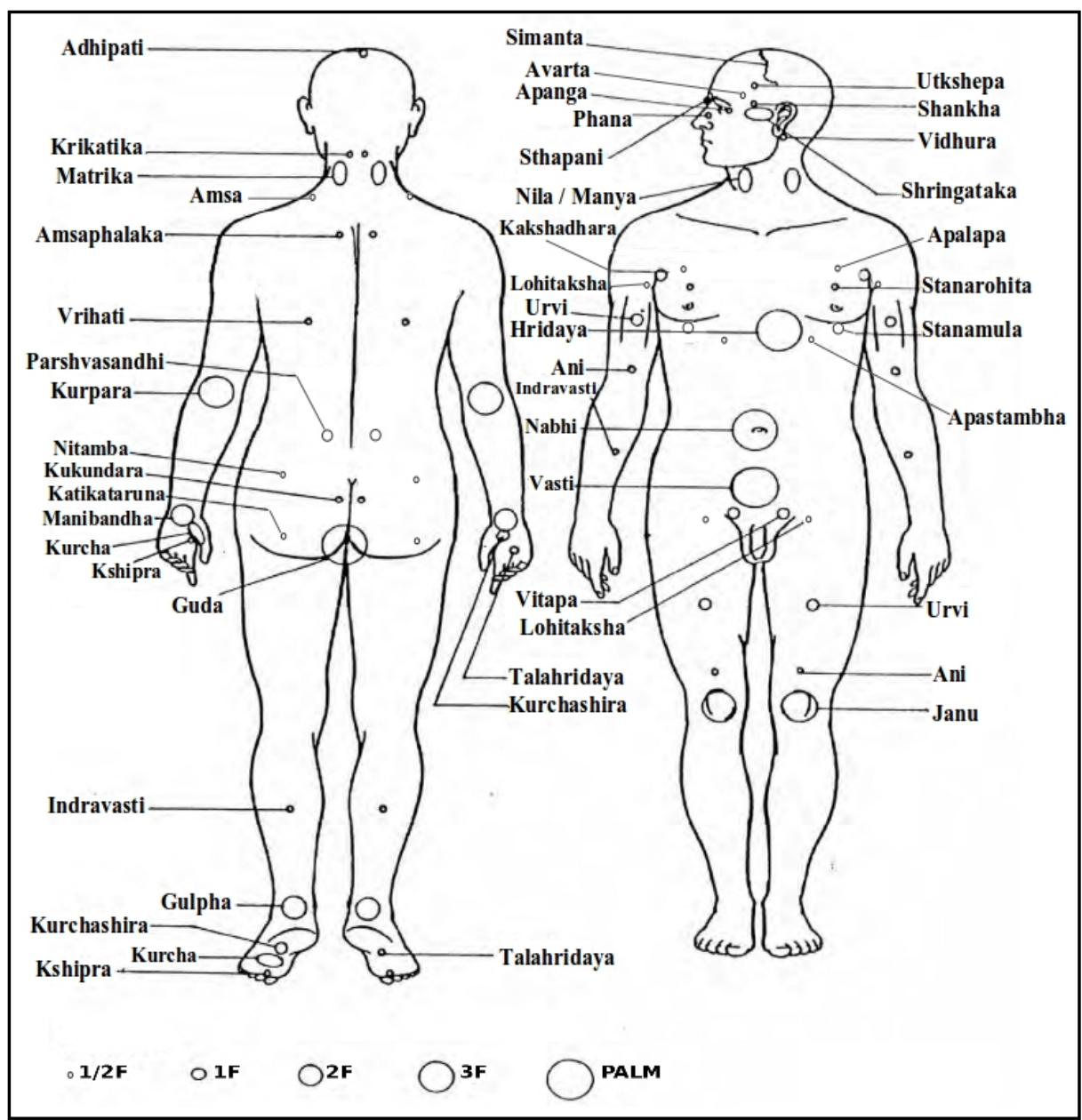

Figure 1. Location and size of individual Marmas in the Shadanga Sharira (entire body) (Courtesy Fedorova, 1990 (35)). 1/2F means half finger size, $1 \mathrm{~F}$ means one finger size, $2 \mathrm{~F}$ means two finger size, 3F means three finger size, and PALM means one palm or one fist size.

\begin{tabular}{|c|c|c|c|c|c|}
\hline \multicolumn{6}{|c|}{ Marmas of Lower Extremities (22 in number) } \\
\hline S. & Marma & Location $(1,3,10)$ & Anatomical Correlation (3) & Size (1) & No. \\
\hline 1 & Talahridaya & 6 fingers proximal to $3^{\text {rd }}$ toe, center of sole & $1^{\text {st }}$ Inter Metatarsal Ligament & 1/2finger & 2 \\
\hline 2 & Kshipra & Between $2^{\text {nd }}$ toe and big toe (in the web) & Long Planter Ligament & 1/2finger & 2 \\
\hline 3 & Kurcha & $\begin{array}{l}\text { About } 1 \text { finger proximal to metatarso-phalayngeal joint of big } \\
\text { toe, over the sole }\end{array}$ & Tarsometatarsal \& Intertarsal Ligament & 1 palm & 2 \\
\hline 4 & Kurchashira & $\begin{array}{l}\text { On either side (medial and lateral) over the heel, below ankle } \\
\text { joint }\end{array}$ & Lateral Ligament of the Ankle Joint & 1 finger & 2 \\
\hline 5 & Gulpha & Ankle joint & Ankle joint & 2 finger & 2 \\
\hline 6 & Indravasti & $\begin{array}{l}\text { In the mid-line, between } 2 \text { bellies of gastrocnemius muscle - } \\
\text { lower leg's center }\end{array}$ & Calf Muscles & 1/2finger & 2 \\
\hline 7 & Janu & Knee joint & Knee joint & 3 finger & 2 \\
\hline 8 & Ani & 3 fingers above knee joint - upper leg's lower part & Tendon of Quadriceps Femoris & 1/2finger & 2 \\
\hline 9 & Urvi & Upper thigh's mid region & Femoral Vessels & 1 finger & 2 \\
\hline 10 & Lohitaksha & Leg's upper part - below inguinal canal & Iliac Vessels & 1/2finger & 2 \\
\hline 11 & Vitapa & Between testicles and inguinal canal & Inguinal Ligament & 1 finger & 2 \\
\hline
\end{tabular}

Table 6. Location, anatomical correlation, size and number of Marmas of Lower Extremities. 


\begin{tabular}{llllll}
\hline \multicolumn{7}{l}{ Marmas of Abdomen (3 in number) } & & \\
\hline S. & Marma & Location (1,3,10) & Anatomical Correlation(3) & Size(1) & No. \\
\hline 1 & Guda & Anus and the area surrounding it & Anal Canal and Anus & 1 palm & 1 \\
\hline 2 & Vasti & In lower abdomen area - behind and above pubic symphysis & Urinary Bladder & 1 palm & 1 \\
\hline 3 & Nabhi & In and around navel & Umblicus & 1 palm & 1 \\
\hline
\end{tabular}

Table 7. Location, anatomical correlation, size and number of Marmas of Abdomen.

\begin{tabular}{|c|c|c|c|c|c|}
\hline \multicolumn{6}{|c|}{ Marmas of Thorax (9 in number) } \\
\hline S. & Marma & Location $(1,3,10)$ & Anatomical Correlation (3) & Size(1) & No. \\
\hline 1 & Hridaya & In thoracic cage's middle area, slightly to the left & Heart & 1 fist & 1 \\
\hline 2 & Stanamula & 2 finger below nipples' level (at about $6^{\text {th }}$ intercostal space) & Internal Mammary Vessels & 1 finger & 2 \\
\hline 3 & Stanarohita & Breast's upper region (at about $2^{\text {nd }}-3^{\text {rd }}$ intercostal space) & Lower Part of Pectoralis Major Muscle & 1/2finger & 2 \\
\hline 4 & Apalapa & On top of flanks and below shoulder joint & $\begin{array}{l}\text { Lateral Thoracic and Subscapular } \\
\text { Vessel }\end{array}$ & 1/2finger & 2 \\
\hline 5 & Apastambha & On either side of sternum, at $2^{\text {nd }}$ intercostal space & Two Bronchi & 1/2finger & 2 \\
\hline
\end{tabular}

Table 8. Location, anatomical correlation, size and number of Marmas of Thorax.

\begin{tabular}{|c|c|c|c|c|c|}
\hline \multicolumn{6}{|c|}{ Marmas of Back (14 in number) } \\
\hline S. & Marma & Location $(1,3,10)$ & Anatomical Correlation (3) & Size (1) & No. \\
\hline 1 & Amsa & $\begin{array}{l}\text { On top of back, between arm and neck - vertically parallel } \\
\text { to either sacro-iliac(SI) joint }\end{array}$ & $\begin{array}{l}\text { Coraco-humoral, Gleno-humoral } \\
\text { Ligament, Trapezius Muscle }\end{array}$ & $1 / 2$ finger & 2 \\
\hline 2 & Amsaphalaka & Shoulder blade - just medial to scapular spine's root & Scapular Spine & $1 / 2$ finger & 2 \\
\hline 3 & Vrihati & $\begin{array}{l}\text { In line with either sacro-iliac(SI) joint - just above the level } \\
\text { of scapula's inferior angle }\end{array}$ & $\begin{array}{l}\text { Subscapular and Transverse Cervical } \\
\text { Arteries }\end{array}$ & $1 / 2$ finger & 2 \\
\hline 4 & Parshvasandhi & $\begin{array}{l}\text { Below the } 12^{\text {th }} \text { rib's inferior border, between flanks and } \\
\text { buttock, at Renal angle }\end{array}$ & Common Iliac Vessels / Renal Angles & 1 finger & 2 \\
\hline 5 & Nitamba & Buttock's upper region & Ischial Tuberosity & $1 / 2$ finger & 2 \\
\hline 6 & Kukundara & On lower iliac spine's either side & Sacroiliac Joint & $1 / 2$ finger & 2 \\
\hline 7 & Katikataruna & $\begin{array}{l}\text { Over the line joining ischial tuberosity and femur's greater } \\
\text { trochanter }\end{array}$ & Sciatic Notch & $1 / 2$ finger & 2 \\
\hline
\end{tabular}

Table 9. Location, anatomical correlation, size and number of Marmas of Back.

\section{Marmaghata (Injury to the Marma Points)}

As described earlier, injury to the Marma points, i.e. Marmaghata, can lead to severe pain, loss of sensation, loss of function, disability, and death. A significant portion of Shalya Tantra (science of surgery) deals with the knowledge of the fatal spots (marmas), because any injury to these fatal spots leads to sudden death, and if anyone survives due to the efficiency of the physician, the occurrence of deformities is almost a certainty (Sushruta Sharira 6/33) (1). 


\begin{tabular}{|c|c|c|c|c|c|}
\hline \multicolumn{6}{|c|}{ Marmas of Supraclavicular region (37 in number) } \\
\hline S. & Marma & Location $(1,3,10)$ & Anatomical Correlation (3) & Size (1) & No. \\
\hline 1 & Nila & Just lateral to trachea - at throat's base & Right and Left Common Carotid Artery & 1 palm & 2 \\
\hline 2 & Manya & $\begin{array}{l}\text { About } 1 / 2 \text { finger downwards and posterior to angle of } \\
\text { mandible - side of upper neck }\end{array}$ & $\begin{array}{l}\text { Right Sub-clavian Artery and Internal } \\
\text { Jugular Veins }\end{array}$ & 1 palm & 2 \\
\hline 3 & Matrika & neck's both sides & Blood Vessels of the Neck & 1 palm & 8 \\
\hline 4 & Krikatika & $\begin{array}{l}\text { Joint of neck and head - just on occipital protuberance's } \\
\text { inferior part }\end{array}$ & Atlanto Occipital Articulation & 1/2finger & 2 \\
\hline 5 & Vidhura & Below and at the back of ears & Posterior Auricular Ligament & 1/2finger & 2 \\
\hline 6 & Phana & Ala nasi's either side & $\begin{array}{l}\text { Kiesselbach's Plexus in Little's Area of } \\
\text { Nose }\end{array}$ & 1/2finger & 2 \\
\hline 7. & Apanga & Eyes' outer corner & Zygomatico-temporal Vessels & 1/2finger & 2 \\
\hline 8. & Avarta & At eyebrows' center - in orbital cavity's upper border & $\begin{array}{l}\text { Junction of Frontal, Molar \& Sphenoid } \\
\text { Bone }\end{array}$ & 1/2finger & 2 \\
\hline 9. & Utkshepa & At hairline's border - above the temples & Temporal Muscles and Fascia & 1/2finger & 2 \\
\hline 10. & Shankha & On top of temples & Temples & 1/2finger & 2 \\
\hline 11. & Sthapani & On front of forehead - between the eyebrows & Nasal Arch of the Frontal Vein & 1/2finger & 1 \\
\hline 12. & Shringataka & $\begin{array}{l}\text { At the Center of confluence of veins that supply } \\
\text { nourishment to eyes, ears, nose and tongue }\end{array}$ & Cavernous and Inter-cavernous sinuses & 1 palm & 4 \\
\hline 13. & Simanta & Fissure on skull & Cranial Sutures & 1 palm & 5 \\
\hline 14. & Adhipati & Top of head & Torcular Harophili & 1/2finger & 1 \\
\hline
\end{tabular}

Table 10. Location, anatomical correlation, size \& number of Marmas of Supraclavicular region.

\section{Common symptoms of Marmaghata}

According to Acharya Sushruta (Sushruta Sutra 25/34-35) (1), the common symptoms of

Marmaghata are as follows:

भ्रम: प्रलाप: पतनं प्रमोहो विचेष्टनं संलयनोष्णते च। स्रस्तान्गता मूर्च्छनमूर्ध्ववास्तीव्रा रुजो वातकृताश्च तास्ता:॥ मांसोदकाभं रुधिरन्च गच्छेत् सर्वेन्द्रियार्थो परमस्तथैव। दशार्धसंख्येष्वपि हि क्षतेषु सामान्यतो मर्मसु लिंगमुक्तम्।।

(Sushruta Sutra 25/34-35) (1)

- $\quad$ Bhrama (Giddiness)

- Pralapa (Delirium)

- $\quad$ Patana (Fainting)

- Pramoha (Delusion)

- Vicheshtana (Loss of activity of the body parts)

- Sanlayana (Semi- consciousness)

- Ushnataa (Increase of body temperature)

- Srastaangataa (weakness of body parts)
- $\quad$ Murchha (Fainting)

- $\quad$ Urdhwavata (Increased expiration)

- Vatastivra ruja (Severe pain caused by Vata)

- Mansadokabham rudhiram cha gachchheta (Flowing out blood resembling meat washed fluid)

- Sarvendriyaarthoparamastathaiva (Cessation of activity of all sense organs) are the common symptoms when all the five vital spots (mansa, sira, snayu, asthi, sandhi) are injured.

\section{Symptoms of Marma Kshata/ Marma Viddha}

Table 11 lists the symptoms of Marma Kshata / Marma Viddha (injury or piercing of Marma point) according to Acharya Sushruta (Sushruta Sutra 25/36-40) (1) and Acharya Vagbhatta (Ashtanga Hridaya Sharira 4/47-51) (2). Table 12 lists the symptoms of Marmaghata according to the vulnerability of Marmas. 


\begin{tabular}{|c|c|c|c|c|c|}
\hline s. & $\begin{array}{l}\text { Type of } \\
\text { Marma }\end{array}$ & No. & Name of Marmas & $\begin{array}{l}\text { Marma Viddha lakshanas } \\
\text { (Acharya Sushruta) } \\
\text { (Sushruta Sutra 25/36-40) (1) }\end{array}$ & $\begin{array}{l}\text { Marma Viddha lakshanas } \\
\text { (Acharya Vagbhatta) } \\
\text { (Ashtanga Hridaya Sharira 4/47-51) (2) }\end{array}$ \\
\hline 1 & $\begin{array}{l}\text { Mamsa } \\
\text { Marma }\end{array}$ & 10 & $\begin{array}{l}\text { Talahridaya, Indravasti, } \\
\text { Stanarohita }\end{array}$ & $\begin{array}{l}\text { Loss of touch sensation, Vipaandutaa } \\
\text { (profound yellowish white color of body) }\end{array}$ & $\begin{array}{l}\text { Continuous bleeding, blood resembles meat } \\
\text { washed water, consistency of blood is thin, } \\
\text { pandu, loss of function of sense organs, causes } \\
\text { immediate death }\end{array}$ \\
\hline
\end{tabular}

\begin{tabular}{|c|c|c|c|c|c|}
\hline 2 & $\begin{array}{l}\text { Sira } \\
\text { Marma }\end{array}$ & 37 & $\begin{array}{l}\text { Urvi, Lohitaksha, Vitapa, } \\
\text { Kakshadhara, Nabhi, Hridaya, } \\
\text { Stanamula, Apalapa, } \\
\text { Parshvasandhi, Vrihati, Nila, } \\
\text { Manya, Matrika, Phana, } \\
\text { Sthapani }\end{array}$ & $\begin{array}{l}\text { Intense bleeding from the wound, color } \\
\text { of blood resembles indragopa (bright red } \\
\text { colored conchial insect), Vata gets } \\
\text { aggravated and causes many diseases }\end{array}$ & $\begin{array}{l}\text { Thick blood flows out continuously and in large } \\
\text { quantity, thirst, dizziness, breathlessness, } \\
\text { delirium, hiccough and ultimately leads to death }\end{array}$ \\
\hline 3 & $\begin{array}{l}\text { Snayu } \\
\text { Marma }\end{array}$ & 23 & $\begin{array}{l}\text { Kurcha, Kurchsira, Kshipra, Ani, } \\
\text { Vasti, Ansa, Apanga, Utkshepa }\end{array}$ & $\begin{array}{l}\text { Shortening, debility of body parts, that } \\
\text { i, become unable to perform their actions, } \\
\text { excruciating pain, wound healing takes } \\
\text { longer time }\end{array}$ & $\begin{array}{l}\text { Ayama (distension), Akshepaka (convulsions), } \\
\text { Jadata (stiffness), severe pain, inability to sit, } \\
\text { stand, ride etc., causes distortions or even death }\end{array}$ \\
\hline 4 & $\begin{array}{l}\text { Sandhi } \\
\text { Marma }\end{array}$ & 20 & $\begin{array}{l}\text { Gulpha, Janu, Manibandha, } \\
\text { Kurpara, Krikatika, Kukundara, } \\
\text { Avarta, Simanta, Adhipati }\end{array}$ & $\begin{array}{l}\text { profuse swelling, severe pain, loss of } \\
\text { strength of joints, splitting pain, oedema, } \\
\text { and loss of function of joints }\end{array}$ & $\begin{array}{l}\text { The site of injury feels like full of thorns, even } \\
\text { after healing of the wound there is shortening of } \\
\text {, limb, lameness, diminution of strength and } \\
\text { movement, atrophy, swelling of joints }\end{array}$ \\
\hline 5 & $\begin{array}{l}\text { Asthi } \\
\text { Marma }\end{array}$ & 08 & $\begin{array}{l}\text { Katikataruna, Nitamba, } \\
\text { Ansaphalaka, Shankha }\end{array}$ & $\begin{array}{l}\text { Severe and constant pain during day } \\
\text { and night, finds no comfort in any } \\
\text { posture, thirst, body weakness, oedema, } \\
\text { pain }\end{array}$ & $\begin{array}{l}\text { Intermittent discharge of clear fluid mixed with } \\
\text {, majja, associated with pain }\end{array}$ \\
\hline 6 & $\begin{array}{l}\text { Dhamani } \\
\text { Marma }\end{array}$ & 09 & $\begin{array}{l}\text { Guda, Apastambha, Vidhura, } \\
\text { Shringataka }\end{array}$ & & $\begin{array}{l}\text { Frothy and warm blood flows out with sound, } \\
\text { person become unconscious }\end{array}$ \\
\hline
\end{tabular}

Table 11. Symptoms of Marma Kshata / Marma Viddha according to Acharya Sushruta (1) and Acharya Vagbhatta (2).

\begin{tabular}{|c|c|c|c|c|c|}
\hline S & Type of Marma & No. & Trigunas & Bhutas & $\begin{array}{l}\text { Prognosis/ Symptom of Marmaghata } \\
\text { (Sushruta Sharira 6/36-40) (1) and } \\
\text { (Ashtanga Hridaya Sharira 4/52-58) (2) }\end{array}$ \\
\hline 1 & $\begin{array}{l}\text { Sadyah } \\
\text { Pranahara }\end{array}$ & 19 & $\begin{array}{l}\text { Rajas \& } \\
\text { Sattva }\end{array}$ & Agni (fire) & $\begin{array}{l}\text { Loss of sensory perception, abnormalities of mind and intellect, different kinds of severe } \\
\text { pain. Immediate death within seven days. } \\
\text { When injured, there is sudden depletion of Agni Guna. }\end{array}$ \\
\hline 2 & $\begin{array}{l}\text { Kalantara } \\
\text { Pranahara }\end{array}$ & 33 & $\begin{array}{l}\text { Rajas \& } \\
\text { Tamas }\end{array}$ & $\begin{array}{l}\text { Agni (fire) \& } \\
\text { Soma (water) }\end{array}$ & $\begin{array}{l}\text { Dhatukshya (loss or decrease of Dhatus), loss of consciousness. } \\
\text { Death within fifteen or thirty days of injury. When injured, there is sudden depletion of } \\
\text { Agni Guna, followed by gradual depletion of Soma Guna. }\end{array}$ \\
\hline 3 & Vishalyaghna & 03 & Rajas & Vayu (air) & $\begin{array}{l}\text { Vayu escapes when Shalya (foreign material) is removed and results in death. Vayu, } \\
\text { mansa, vasa, majja and mastulunga are dried; shwasa, kasa develops and destroys the } \\
\text { life of the person. }\end{array}$ \\
\hline 4 & Vaikalyakara & 44 & Tamas & Soma (water) & $\begin{array}{l}\text { Sthirattvam (stable) and Shaityam (cold) property of Soma leads to Pranavalambana } \\
\text { (holds Prana - that is why it helps in sustenance of life), but results in deformity }\end{array}$ \\
\hline 5 & Rujakara & 08 & $\begin{array}{l}\text { Rajo } \\
\text { bahulya }\end{array}$ & $\begin{array}{l}\text { Vayu (air) + } \\
\text { Agni (fire) }\end{array}$ & Any injury results in pain (Agni is Ashukari - quick acting, and Vayu produces pain) \\
\hline
\end{tabular}

Table 12. Symptoms of Marmaghata according to vulnerability of Marmas. 
Specific Symptoms of Marmaghata for Individual Marmas

\begin{tabular}{|c|c|c|c|}
\hline S & Marma & Effect of trauma & Resultant \\
\hline 1 & Kshipra & Death due to convulsions & Delayed fatal \\
\hline 2 & Talahridaya & Death due to severe pain & Delayed fatal \\
\hline 3 & Kurcha & Wrist drop / Foot drop and tremors & Disabling \\
\hline 4 & Kurchashira & Prain and swelling & Painful \\
\hline 5 & Manibandha & Pain, wrist drop and deformity & Painful \\
\hline 6 & Gulpha & Pain, restricted ankle movement and deformity & Painful \\
\hline 7 & Indravasti & Excessive haemorrhage and death & Delayed fatal \\
\hline 8 & Kurpara & Non- functioning and deformity of forearm & Disabling \\
\hline 9 & Janu & Non- functioning and deformity of leg & Disabling \\
\hline 10 & Ani & Excessive swelling and dysfunction of limb & Disabling \\
\hline 11 & Urvi & Haemorrhage and atrophy of limb & Disabling \\
\hline 12 & Lohitaksha & Excessive bleeding, paralysis and death & Disabling \\
\hline 13 & Kakshadhara & Paralysis & Disabling \\
\hline 14 & Vitapa & Impotency or decreased semen discharge & Disabling \\
\hline 15 & Guda & Immediate death & Immediate fatal \\
\hline 16 & Vasti & Immediate death & Immediate fatal \\
\hline 17 & Nabhi & Immediate death & Immediate fatal \\
\hline 18 & Hridaya & Immediate death & Immediate fatal \\
\hline 19 & Stanarohita & Haemothorax, cough, breathlessness and death & Delayed fatal \\
\hline 20 & Stanamula & Pleural effusion, cough, breathlessness and death & Delayed fatal \\
\hline 21 & Apalapa & Pyaemia, septicemia and death & Delayed fatal \\
\hline 22 & Apastambha & Pneumothorax, cough, breathlessness and death & Delayed fatal \\
\hline 23 & Katikataruna & Excessive haemorrhage, severe anaemia and death & Delayed fatal \\
\hline 24 & Kukundara & Loss of sensation and locomotive activity & Disabling \\
\hline 25 & Nitamba & Atrophy of lower limbs and death & Delayed fatal \\
\hline 26 & Parshvasandhi & Renal injury, retroperitoneal haemorrhage \& death & Delayed fatal \\
\hline 27 & Vrihati & Haemorrhagic complications and death & Delayed fatal \\
\hline 28 & Ansaphalaka & Numbness and paresis of upper limbs & Disabling \\
\hline 29 & Ansa & Stiff shoulder & Disabling \\
\hline 30 & Krikatika & Instability of head, continuous movement of head & Disabling \\
\hline 31 & Nila & Aphonia, dysphonia and loss of taste & Disabling \\
\hline 32 & Manya & Aphonia, dysphonia and loss of taste & Disabling \\
\hline 33 & Matrika & Sudden death & Immediate fatal \\
\hline 34 & Vidhura & Deafness & Disabling \\
\hline 35 & Phana & Anosmia (loss of smell sensation) & Disabling \\
\hline 36 & Apanga & Blindness or Diminution of vision & Disabling \\
\hline 37 & Avarta & Blindness or Diminution of vision & Disabling \\
\hline 38 & Utkshepa & Death, if foreign body removed & Fatal after removal of foreign body \\
\hline 39 & Sankha & Sudden death & Immediate fatal \\
\hline 40 & Sthapani & Death, if foreign body removed & Fatal after removal of foreign body \\
\hline 41 & Simanta & Madness, phobia, chittanasha, death & Delayed fatal \\
\hline 42 & Sringataka & Sudden death & Immediate fatal \\
\hline 43 & Adhipati & Sudden death & Immediate fatal \\
\hline
\end{tabular}

Table 13. Specific symptoms of Marmaghata for Individual Marmas (Sushruta Sharira 6/25-28) (1) and (Ashtanga Hridaya Sharira 4/2-36) (2).
Table 13 gives the specific symptoms of Marmaghata for individual Marma points. 


\section{Symptoms caused by Marmaghata of Trimarmas}

Table 14 lists the symptoms caused by Marmaghata of Trimarmas.

\begin{tabular}{|c|c|c|}
\hline S & Marma & Symptom of Marmaghata (Charak Siddhi 9/6) (51) \\
\hline 1 & Hridaya & $\begin{array}{l}\text { Kasa (cough), shwasa (breathlessness), balakshya (debility), kanthashosh (dryness of throat), traction of kloma, } \\
\text { mukhatalushosha (dryness of mucous membrane of oral cavity), jihwa nirgaman (protraction of tongue), different types } \\
\text { of psychotic disorders like apasmara (epilepsy), unmada (insanity), pralapa (delirium), chittanasha (emptiness of } \\
\text { mind), etc. }\end{array}$ \\
\hline
\end{tabular}

\begin{tabular}{ll}
\hline & Manyastambha (neck stiffness), ardita (facial paralysis), chakshurvibhrama (rolling of eye balls), moha (mental \\
& confusion), uddveshtana (cramps), cheshtanasha (loss of movement), cough, shwasa (breathlessness), hanugre \\
& (locked jaw), mooka (muteness), gadgadatva (stammering), akshinimilan (drooping of eyelids - ptosis), \\
& gandaspandana (quivering of cheeks), jrambha (yawning), lalashrava (salivation), swarahani (loss of voice), \\
& deformation of face, etc.
\end{tabular}

Apanavayu-mutra-varchanigraha (retention of flatus, urine and faeces), vankshana - mehana-vasti shoola (pain in

$3 \quad$ Vasti groin, penis and urinary bladder), kundala, udavarta, gulma, vatashthila, upastambha (stiffness), nabhikukshigudashronigraha (spasm in navel, lower abdomen, anus and hip region), etc.

Table 14. Symptoms caused by Marmaghata of Trimarmas

\section{Samprapti of Marmabhighata}

The Samprapti of Marmabhighata can be understood from the following flowchart (Figure 2) (Sushruta

\section{Sharira 6/18-20) (1) and (Ashtanga Hridaya Sharira $4 / 64,65)(2)$.}

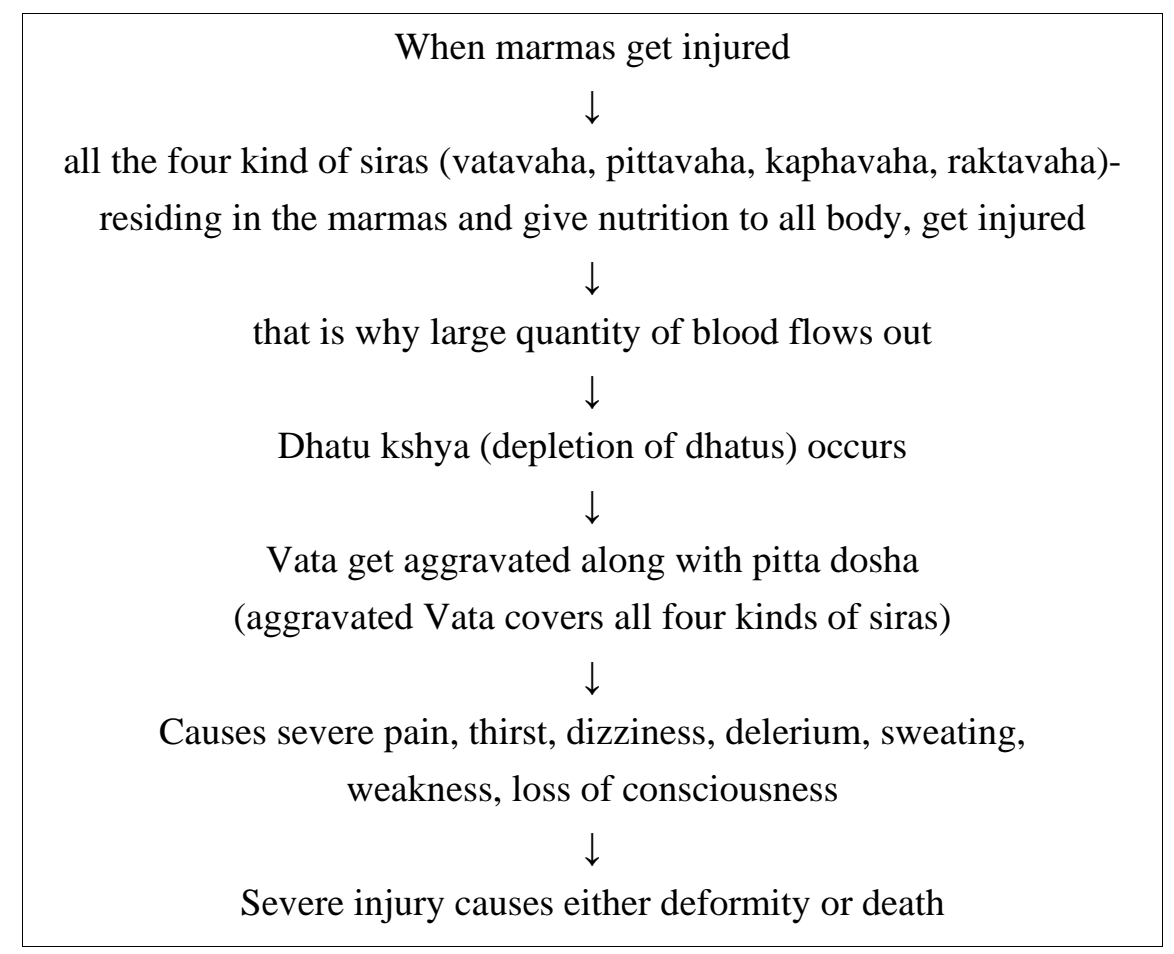

Figure 2. Samprapti of Marmabhighata. 


\section{Chikitsa of Marmabhighata}

The chikitsa (treatment) of Marmabhighata is done in the following ways (Charaka Chikitsa 26) (51), (Sushruta Chikitsa 1, 2) (1):

- Lakshanika chikitsa (symptomatic treatment) according to marma viddha lakshanas

- Vata vyadhi chikitsa

- Judicial selection of Shashti upakrama, for vranopachara

\section{Conclusion}

The present article explored the foundational elements of the Science of Marma with regards to the number of marmas, their location, structures involved, correlation with Panchamahabhutas, classification, as well as a detailed explanation of marmaghata or viddha lakshanas (effect of trauma), as given in classical texts written during Samhita kala. The anatomical correlation with modern science has also been presented.

It is observed that the Marmas are of different sizes varying from ardha-anguli (half finger) to hatheli (palm). If injured, different Marmas lead to different kind of symptoms varying from pain to immediate death.

In such a case, several methodologies for the treatment of Marmabhighata have also been suggested in the scriptures. Thus, an in-depth knowledge about the properties of Marmas is available in the scriptures.

The Part-3 of the exploration of the Science of Marma will deal with the foundational elements and current status of Marma Therapy, which is a relatively recent application of this ancient science.

\section{Compliance with ethical standards}

The authors have maintained necessary ethical standards while conducting the study.

\section{Conflict of interest}

The authors declare that they have no conflict of interest.

\section{References}

1. Murthy KRS. Susruta samhita. volume I, II, III. Varanasi, Uttar Pradesh, India: Chaukhambha Orientalia; 2008.

2. Gupta KA. Ashtanga hrdyam of vagbhata - vidyotini hindi commentary. Varanasi, Uttar Pradesh, India: Chaukhamba Sanskrit Sansthan; 2005.

3. Joshi SK. Marma science and principles of marma therapy. 1st ed. Haridwar, Uttarakhand, India: Vani Publications; 2010.

4. Joshi SK. Marma chikitsa vigyan (Hindi). Haridwar, Uttarakhand, India: Mrityunjay Mission; 2012.

5. Joshi SK. Marma vigyan evam chikitsa - vaidik chikitsa vigyan (Hindi). Haridwar, Uttarakhand, India: Mrityunjay Mission; 2011.

6. Joshi SK. Marma vigyan evam aushadhopachar dwara chikitsa (Hindi). Haridwar, Uttarakhand, India: Mrityunjay Mission; 2013.

7. Frawley D, Ranade S, Lele A. Ayurveda and marma therapy. Delhi, India: Chaukhamba Sanskrit Pratishthan; 2015.

8. Lad V, Durve A. Marma points of ayurveda. Albuquerque, New Mexico, USA: The Ayurvedic Press; 2015.

9. Schrott E, Raju JR, Schrott S. Marma therapy. (Translated by) Lorys M. London, UK: Singing Dragon; 2016.

10. Phull G, Phull R. Clinical approach to marma chikitsa. New Delhi, India: IP Innovative Publication Pvt. Ltd.; 2019.

11. Phull G, Phull R. Marma vigyana ka chikitsiya upayoga (Hindi). New Delhi, India: IP Innovative Publication Pvt. Ltd.; 2019.

12. Denaud P. Kalaripayat - the martial arts tradition of India. (Translated by) Cain J. Vermont, USA: Destiny Books; 2009.

13. Fox M, Dickens A, Greaves C, Dixon M, James M. Marma therapy for stroke rehabilitation - a pilot study. Journal of Rehabilitation Medicine. 2006;38(4):268-271. https://doi.org/10.1080/16501970600630820 
14. Kotelevskiy VI. Integrative technology of massage manipulations in physical rehabilitation of students with backbone pathology. Pedagogics, Psychology, MedicalBiological Problems of Physical Training and Sports. 2016;20(3):31-40. https://doi.org/10.15561/18189172.2016.0305

15. Murota M, Iwawaki Y, Uebaba K, Yamamoto Y, Takishita Y, Harada K, Shibata A, Narumoto J, Fukui K. Physical and psychological effects of head treatment in the supine position using specialized ayurveda-based techniques. The Journal of Alternative and Complementary Medicine. 2016;22(7):526-532. https://doi.org/10.1089/acm.2015.0388

16. Sieler R. Kalari and vaittiyacalai: medicine and martial arts intertwined. Asian Medicine. 2012; 7(1): 164-195. https://doi.org/10.1163/15734218-12341247

17. Pathak AK. A study on anatomical concept of kurpara marma and its therapeutic application in grivavata (cervical spondylosis). Thesis for the degree of Doctor of Philosophy (Ph.D.) in Rachana Sharir. Varanasi, Uttar Pradesh, India: Banaras Hindu University; 2015. https://shodhganga.inflibnet.ac.in/handle/10603/267960

18. Dharmesh K. Optimization of individual performance in football by augmenting classical Indian marma therapy, kinesiology-taping and related physical excercises through supportive bio-mechanical parameter. Thesis for the degree of Doctor of Philosophy (Ph.D.) in Physical Education. Tiruchirappalli, Tamil Nadu, India: Bharathidasan University; 2017. https://shodhganga.inflibnet.ac.in/handle/10603/220290)

19. Bedekar SS. A critical study of gulpha marma in basket ball players with special reference to the role of mash tail along with snehan and swedan as preventive measure. Thesis for the degree of Doctor of Philosophy (Ph.D.) in Ayurved. Pune, Maharashtra, India: Tilak Maharashtra Vidyapeeth; 2007. https://shodhganga.inflibnet.ac.in/handle/10603/34851)

20. Rajeshwari PN. A study on rujakara marma and management of viddha laxanas - a clinical study. Dissertation for the degree of Ayurveda Dhanwanthari (M.S.-Shalya Tantra). Bengaluru, Karnataka, India: Rajiv Gandhi University of Health Sciences;

2010.

http://52.172.27.147:8080/jspui/handle/123456789/6831)

21. Vivek J. A comprehensive study on marma \& acupuncture points and evaluation of their therapeutic importance. Dissertation for the degree of Master of Surgery (Ayurveda Dhanvantari) in Shalya Tantra. Bengaluru, Karnataka, India: Rajiv Gandhi University of Health Sciences; 2011. http://52.172.27.147:8080/jspui/handle/123456789/4737

22. Lele A, Ranade S, Frawley D. Secrets of marma - the lost secrets of ayurveda. Delhi, India: Chaukhamba Sanskrit Pratishthan; 2005.
23. Srivastava VK, Srivastava A. Hand book on marma and panchakarma therapy. Varanasi, Uttar Pradesh, India: Chaukhambha Orientalia; 2019.

24. Pathak AK. Anatomy of marma. (Editor) Awasthi HH. Varanasi, Uttar Pradesh, India: Chaukhambha Orientalia; 2014.

25. Mishra JN. Marma and its management. Varanasi, Uttar Pradesh, India: Chaukhambha Orientalia; 2016.

26. Govindan SV. Massage therapy for diseases of vital areas (marma treatment). New Delhi, India: Abhinav Publications; 2005

27. Banjare H. Marma - eka adhyayana, acupressure chikitsa paddhati ke vishesha shandarbha me. Dissertation for the degree of Ayurveda Vachaspati (M.D. - Ayurveda) in Rachana Sharira. Raipur, Chhattisgarh, India: Pt. Ravishankar Shukla University; 2009. https://shodhganga.inflibnet.ac.in/handle/10603/41426

28. Ismail SMB. Marmas in ayurveda and their explanation according to modern anatomy. Thesis for the degree of Doctor of Philosophy (Ph.D.) in Ayurveda. Pune, Maharashtra, India: Savitribai Phule Pune University; 1984. https://shodhganga.inflibnet.ac.in/handle/10603/145863)

29. Kumar CS. A comprehensive study of marmas with special reference to Ayurvedic and Tamil marma sastras in relation to its applied anatomy. Thesis for the degree of Doctor of Philosophy (Ph.D.) in Ayurveda. Kalady, Kerala, India: Sree Sankaracharya University of Sanskrit; 1999. https://shodhganga.inflibnet.ac.in/handle/10603/136019)

30. Muley SK. Ayurvediya sanhitokta marma vichara, vaikalyakara marmanche mahatva evam janumarmachya vaikalyakaratvachi uparugna paddhatine punarpadatalani eka abhyasa (Marathi). Thesis for the degree of Doctor of Philosophy (Ph.D. - Ayurveda) in Sharira Rachana. Nanded, Maharashtra, India: Swami Ramanand Teerth Marathwada University; 2007. https://shodhganga.inflibnet.ac.in/handle/10603/240135

31. Parameswaran S. A comprehensive study on sandhi marma shareera w.s.r. to manibandha marma and its injuries (trauma). Dissertation for the degree of Doctor of Medicine (M.D. Ayurveda) in Shareera Rachana. Bengaluru, Karnataka, India: Rajiv Gandhi University of Health Sciences; 2012. http://52.172.27.147:8080/jspui/handle/123456789/7127

32. Vijayanath V. A comprehensive study of marmas in the hasta (hand) w.s.r. to the surface and regional anatomy (cadaver dissection). Dissertation for the degree of Doctor of Medicine (M.D. - Ayurveda) in Shareera Rachana. Bengaluru, Karnataka, India: Rajiv Gandhi University of Health Sciences; 2011. http://52.172.27.147:8080/jspui/handle/123456789/4578 
33. Vipin PC. A comprehensive study on gulpha sandhi shareera w.s.r. to sports injuries. Dissertation for the degree of Doctor of Medicine (Ayurveda) in Shareera Rachana. Bengaluru, Karnataka, India: Rajiv Gandhi University of Health Sciences; 2011. http://52.172.27.147:8080/jspui/handle/123456789/4579

34. Thatte DG. Acupuncture, marma and other asian therapeutic techniques. Varanasi, Uttar Pradesh, India: Chaukhambha Orientalia; 2015.

35. Fedorova M. Die Marmantheorie in der klassischen indischen Medizin (German) (English translation of the title the marma theory in classical Indian medicine). Thesis for the degree of Doctor of Philosophy (Ph.D.). Munich, Bavaria, Germany: Ludwig-Maximilians-Universität München; 1990. https://archive.org/details/DieMarmantheorieInDerKlassischenI ndischenMedizinFedorova1990/page/n12/mode/2up

36. Mishra A, Shrivastava V. Exploring the science of marma an ancient healing technique - part 1: its mention in ancient Indian scriptures. Submitted to the Dev Sanskriti Interdisciplinary International Journa. February 2020.

https://doi.org/10.31219/osf.io/e6mhy

37. Sastri H. Amarakosa. 3rd ed. Varanasi, Uttar Pradesh, India: Chaukhambha Sanskrit 1997. https://archive.org/details/AmaraKoshaWithBhanuDIkshitSansk ritTikaAndHarGovindShastriHindiTikaChowkhamba_201702/m ode/2up

38. Deva RRK. Shabda-kalpadrum - part 1. 3rd ed. Varanasi, Uttar Pradesh, India: The Chowkhamba Sanskrit Series Office; 1967.

(https://archive.org/details/ShabdaKalpaDrumCompleteIn5Volu mnesVidyaVilasPress/mode/2up)

39. Sankhyadhar SC. Raj nighantu - sri narhari pandit (English translation with critical commentary). Sankhyadhar D (compiled). Varanasi, Uttar Pradesh, India: Chaukhambha Orientalia; 2017.

40. Brahmavarchas. Pranashakti : ek divya vibhuti (Hindi). Pandit Shriram Sharma Acharya samagra vangamaya. volume 17. 2nd ed. Mathura, Uttar Pradesh, India: Akhand Jyoti Sansthan; 1998.

41. Sharma, S. Kaya me samaya, pranagni ka jakhira (Hindi). Gayatri Tapobhumi, Matura, Uttar Pradesh, India: Yug Nirman Yojana Vistar 2010. http://literature.awgp.org/book/kaya_men_samaya_pranagni_ka _jakheera/v1.1

42. Sharma, S. Kaya urja evam usaki chamatkari samarthya (Hindi). Gayatri Tapobhumi, Matura, Uttar Pradesh, India: Yug Nirman Yojana Vistar Trust; 2010. http://literature.awgp.org/book/astonishing_power_of_physical_ subtle_energy_of_human/v2.2
43. Sharma, S. The astonishing power of the bio-physical and subtle energies of the human body. Haridwar, India: Shantikunj; 1996.

http://literature.awgp.org/book/astonishing_power_of_physical_ subtle_energy_of_human/v1.1

44. Gupta KA. Astanga samgraha (with Hindi commentary) (Hindi). part 1, 2. Varanasi, Uttar Pradesh, India: Chowkhamba Krishnadas Academy; 2016.

45. Murthy KRS. Astanga samgraha of Vagbhata (text, English translation, notes, indices, etc.). volume II - sarira, nidana, cikitsita and kalpa sthana. Varanasi, Uttar Pradesh, India: Chaukhambha Orientalia; 2018b.

46. Kushwaha HCS. Caraka samhita - Chakrapani tika - second part (Hindi). Varanasi, Uttar Pradesh, India: Chaukhambha Orientalia; 2012.

47. Kunte AM, Navre KRS. Astangahridaya - composed by Vagbhata - with the commentaries (sarvangasundara) of arunadatta and ayurvedarasayana of hemadri. Paradkar $\mathrm{H}$ (editor). 6th edition. Bombay, India; Pandurang Jawaji; 1939. https://archive.org/details/ashtangahrdaya/mode/2up

48. Misra B, Vaisya R. Bhavaprakasa of sribhava misra (including bhavaprakasa nighantu portion) - edited with the 'vidyotini' Hindi commentary, notes and appendix - first part. Varanasi, Uttar Pradesh, India: Chaukhambha Sanskrit Bhawan; 2013.

49. Murthy KRS. Bhavaprakasa of bhavamisra. volume 1 including nighantu portion. Varanasi, Uttar Pradesh, India: Chowkhamba Krishnadas Academy; 2016.

50. Sushruta samhita - shridalhanacharyavirachitaya nibandhasandrahakhyavyakhyaya nidanasthanasya shrigayadasacharyavirachitaya

nyayachandrikakhyapanjikavyakhyaya cha samullasita (श्रीडल्हणाचार्यविरचितया निबन्धसड्ग्रहाख्यव्याख्यया निदानस्थानस्य श्रीगयदासाचार्यविरचितया न्यायचन्द्रिकाख्यपज्जिकाव्याख्यया च समुल्लसिता) (Sanskrit). Hyderabad, Telangana, India; National Institute of Indian Medical Heritage (Central Council for Research in $\begin{array}{llll}\text { Ayurveda } & \text { and Siddha } & \text { CCRAS). }\end{array}$ http://niimh.nic.in/ebooks/esushruta/?mod=read

51. Sharma PV. Charaka-samhita (text with English translation). volume I, II. Varanasi, Uttar Pradesh, India: Chaukhambha Orientalia; 2008.

52. Srivastava S. Sharngadhar samhita (jiwanprada Hindi commentary). 3rd ed. Varanasi, Uttar Pradesh, India: Chaukhambha Orientalia; 2003. 
53. Cyranski C. Purifying purges and rejuvenating massages ayurvedic health tourism in South India. Thesis for the degree of Doctor of Philosophy (Dr. Phil.) in Anthropology. Heidelberg, Baden-Württemberg, Germany: Heidelberg University; 2016. https://archiv.ub.uni-

heidelberg.de/volltextserver/22342/1/Dissertation_Cyranski_201 6.pdf

54. Kamboj M. Concept of marma and its importance: a review. International Journal of Research in Ayurveda \& Pharmacy. 2018; 9(6): 1-3. https://doi.org/10.7897/2277-4343.096161

55. Pai DS. A Study on balya-rasayana and its applicability in sports medicine. Dissertation for the degree of Ayurveda Vachaspati (M.D.) in Ayurveda Siddhanta. Bengaluru, Karnataka, India: Rajiv Gandhi University of Health Sciences; 2010. http://52.172.27.147:8080/jspui/handle/123456789/4431

56. Upendran B. A comprehensive study of siravyadha w.s.r. to anatomical \& marma relevance of the lower extremity. Dissertation for the degree of Ayurveda Vachaspati (M.D.) in Rachana Shareera. Bengaluru, Karnataka, India: Rajiv Gandhi University of Health 2010. http://52.172.27.147:8080/jspui/handle/123456789/4507

57. Wujastyk D. Interpreting the image of the human body in premodern India. International Journal of Hindu Studies. 2009; 13(Article number 2), 189-228. https://doi.org/10.1007/s11407009-9077-0

58. Das B, Ganesh RM, Mishra PK, Bhuyan G. A study on apabahuka (frozen shoulder) and its management by laghumasha taila nasya. Ayu. 2010; 31(4): 488-494. https://doi.org/10.4103/0974-8520.82048

59. Narayanan CR, Korotkov K, Srinivasan TM. Bioenergy and its implication for yoga therapy. International Journal of Yoga. 2018; 11(2): 157-165. https://doi.org/10.4103/ijoy.IJOY_54_17

60. Santwani K, Shukla VD, Santwani MA, Thaker G. An assessment of Manasika Bhavas in menopausal syndrome and its management. Ayu. 2010; 31(3): 311-318. https://doi.org/10.4103/0974-8520.77156

61. Mulay SK, Paranjape MH, Bhingare SD. Study of janu marma in relation to its vaikalyakara effects when injured. International Journal of Research in Ayurveda \& Pharmacy. 2011; 2(3): 715-722. https://ijrap.net/admin/php/uploads/491_pdf.pdf
62. Muley SK, Ingale NN, Bhingare SD. Study of vaikalyakara marma with special reference to kurpara marma. Ayu. 2011; 32(4): 472-477. https://doi.org/10.4103/0974-8520.96118

63. Zate MP, Sadgir MA, Khandare PB. A review on anatomical structures present at sthapani marma with special reference to ayurvedic \& modern view point. International Journal of Research in Ayurveda \& Pharmacy. 2017; 8(6): 48-50. https://doi.org/10.7897/2277-4343.086290

64. Jyothi V. Comprehensive study on gulphasandhi shaareera w.s.r. to its structural changes in amavata. Dissertation for the degree of Doctor of Medicine (M.D. - Ayurveda) in Shareera Rachana. Bengaluru, Karnataka, India: Rajiv Gandhi University of Health 2012. http://52.172.27.147:8080/jspui/handle/123456789/7129

65. Jyothis G. A comprehensive study on charakokta tri vidha marma w.s.r. to 'hridaya'. Dissertation for the degree of Ayurveda Vachaspati (M.D.) in Rachana Shareera. Bengaluru, Karnataka, India: Rajiv Gandhi University of Health Sciences; 2011. http://52.172.27.147:8080/jspui/handle/123456789/4669

66. Kumar ST. A comprehensive study on paada marma w.s.r. to the surface and regional anatomy (cadaver dissection). Dissertation for the degree of Ayurveda Vachaspati (M.D.) in Shareera Rachana. Bengaluru, Karnataka, India: Rajiv Gandhi University of Health Sciences; 2012. http://52.172.27.147:8080/jspui/handle/123456789/7126

67. Shariff SUR. A study on sandhi marma w.s.r. to regional and applied anatomy of kurpara marma. Dissertation for the degree of Doctor of Medicine (M.D. - Ayurveda) in Shareera Rachana. Bengaluru, Karnataka, India: Rajiv Gandhi University of Health Sciences;

2011. http://52.172.27.147:8080/jspui/handle/123456789/4575

68. Swamy SM. A study on prushtha marma w.s.r. to stabdha bahuta in amsa marmabhighata. Dissertation for the degree of Ayurveda Vachaspati (M.D. - Ayurveda) in Rachana Shareera. Bengaluru, Karnataka, India: Rajiv Gandhi University of Health Sciences;

2010 http://52.172.27.147:8080/jspui/handle/123456789/4710 